\title{
TINJAUAN ETIS KRISTEN TERHADAP POLITISASI AGAMA DI INDONESIA
}

\section{Kurnia Sondang Lumban Gaol}

\section{PENDAHULUAN}

Hubungan antara agama dengan politik, menurut Machavelli bahwa peran agama yang terpenting ialah menjadi alat kekuasaan politik. Agama harus berperan sebagai alat pemersatu yang mempersatukan seluruh rakyat dalam ketaatan dan kesetiaan terhadap penguasa demi kejayaan negara. Agama harus menjadi alat pengaruh, alat kekuasaan dan alat pengawasan di tangan sang penguasa terhadap mereka yang dikuasai. ${ }^{1}$ Pandangan tersebut tentu tidak benar, karena Machiavelli tidak memandang agama secara teologis.

Terjadinya politisasi agama tidak bisa dilepaskan dari kebangkitan agama besar pada akhir abad ke-20. Kebangkitan agama tersebut ditandai dengan gerakan keagamaan yang terjadi di hampir semua negara di dunia. Kesadaran beragama bangkit bersamaan dengan gagal dan hancurnya negara-negara yang menganut paham komunisme. ${ }^{2}$ Selanjutnya, Stevri I. Lumintang menyatakan:

Kebangkitan agama-agama besar di dunia ditandai dengan banyaknya tulisan-tulisan berupa buku-buku agama yang dipublikasikan oleh hampir semua agama. Selain itu media elektronika seperti televisi dan jaringan internet, banyak memuat berita-berita bernuansa agama. Kebangkitan agama juga terlihat melalui organisasi-organisasi politik, sosial dan ekonomi yang berbasiskan agama, bukan hanya di tingkat regional dan nasional, melainkan juga di tingkat internasional. ${ }^{3}$

Dengan demikian bahwa spirit perjuangan atas nama agama menguasai berbagai bidang kehidupan manusia. Demikian juga dengan di Indonesia.

Di Indonesia kebangkitan agama ditandai dengan berdirinya banyak bangunan ibadah, maraknya kegiatan-kegiatan agama yang bersifat masa. Bahkan berdirinya gerakan-gerakan ekonomi yang bernuansa agama seperti bank-bank bernuansa agama tertentu. Bukan hanya gerakan ekonomi, juga politik seperti yang ditandai dengan maraknya partai-partai yang berbasiskan agama yang ada di Indonesia, seperti PKB, PAN, PBB, dan PKS. Tidak ketinggalan bidang pendidikan dan hukum digarami oleh agama, sehingga hampir tidak ada bidang yang tidak diagamaisasikan. ${ }^{4}$

1 J.H. Rapar, Filsafat Pilitik: Plato, Aristoteles, Augustinus, Machiavelli, (Jakarta: PT RajaGrafindo Persada, 2001), h. 474-475

${ }^{2}$ Stevri Indra Lumintang, Re-Indonesianisasi Bangsa (Batu: Departemen Multi-Media YPPII, 2009), h. 447

${ }^{3}$ Ibid., h.448

${ }^{4}$ Ibid., h.448-449 


\section{BAB I \\ POLITISASI AGAMA DI INDONESIA}

Konsekuensi terlibatnya agama dalam setiap sendi kehidupan, politisasi agama telah menjadi hal yang berpotensi untuk terjadi. Dalam masyarakat Indonesia yang religius dan paternalistis, penggunaan dan penyalahgunaan agama merupakan cara yang masih dirasakan paling baik Contoh mobilisasi masyarakat dengan melibatkan agama, "Poros Tengah", koalisi beberapa partai Islam yang dimotori oleh Amien Rais pada tahun 1999 berhasil membawa Abdurrahman Wahid (Gus Dur) menjadi presiden RI. Tetapi, pada akhirnya, Amien Rais jugalah yang menjatuhkan Gus Dur pada tahun 2001 .

Bahkan demi kepentingan tertentu, para propagandis tidak segan-segan "menjual" ideologi partainya demi kepentingan sesaat. Sebagai contoh, hal ini terjadi saat sejumlah parpol yang menolak kehadiran Presiden wanita karena bertentangan dengan syariat, visi dan platform partai. Tindakan diskriminatif PPP dan Poros Tengah yang menolak kepemimpinan wanita bukan hanya sekedar wacana, tetapi merupakan kenyataan dalam melakukan manuver dan propaganda politik. Namun kelompok ini kemudian justru mendukungnya demi kekuasaan dan alasan strategis. Hal ini sangat jelas menunjukkan sikap yang tidak konsisten dalam memperjuangkan visi ideologis yang sering digembar-gemborkan. Mereka telah mempolitisir agama yang berakibat rusaknya agama itu sendiri.

Cara lain propaganda politik adalah dengan mendisain simbol dan citra, baik langsung maupun melalui media. Satu kelompok berusaha menyeret-nyeret tokoh agama, pemerintah, atau kelompok tertentu untuk berpihak kepada mereka. Hal ini bukan hanya menciterakan ketidakmandirian parpol itu dan menimbulkan tindakan diskriminatif terhadap kelompok lain, tetapi juga sangat berpotensi memunculkan pertentangan yang lebih buruk pada kelompok masyarakat awam.

Kegiatan berpolitik menjadikan agama sebagai medan pertarungan politis, bisa membawa banyak dampak negatif seperti perusakan rumah ibadah atau pengadudombaan golongan umat beragama. Meskipun bahaya ini bukanlah hal yang khas di Indonesia, tetapi dalam sejarah bangsa kita, isu-isu seperti negara Islam, SARA, mayoritas-minoritas, bahaya islamisasi atau kristianisasi, turut menggalakkan kegiatan untuk mempolitikkan agama dan memberi kesan khas kepada sejarah bangsa kita bahwa agama merupakan problem nasional yang paling mendasar oleh karena pluralisme agama di tanah air. Padahal, isu-isu itu yang merupakan bagian dari politisasi agama bukan tumbuh di kalangan rakyat biasa yang bertahun-tahun hidup damai dan rukun di satu wilayah di antara golongan yang berbeda agama oleh karena ikatan kekeluargaan umpamanya, tetapi tumbuh di kalangan elite yang bermain politik, baik secara lokal maupun secara nasional. Pertarungan politik mereka yang justru mengambil tempat di atas panggung kehidupan beragama, semata-mata merupakan perang kuasa yang sama sekali tidak mempedulikan keutamaan berpolitik yang dilatar-belakangi oleh nilai moral-religius dari agama apa pun. ${ }^{5}$

\footnotetext{
${ }^{5}$ Agama dan Politik, http:/www.Ambil-free.com, 15 Mei 2010
} 
Praktik politisasi agama dan identitas lain adalah ketika RUU Pornografi dibahas di parlemen pada 2007-2008. Semua bangunan logika RUU yang disahkan menjadi UU No 44/2008 akhir 2008 tidak ada yang rasional, baik dari segi filosofis, sosiologis, maupun yuridis. Namun, dengan keyakinan akan meraih keuntungan politik besar pada pemilu legislatif, parlemen memaksakan diri mengesahkan RUU ini menjadi UU. Namun yang terjadi pada Pemilu 2009 bahwa hanya tiga besar diduduki partai-partai nasionalis. Kemenangan Demokrat bukan karena mengusung RUU Pornografi dan kecerdasan melakukan politisasi, tetapi karena faktor "keberhasilan" kinerja SBY yang berhasil dikomunikasikan kepada publik.

Politisasi agama terjadi juga di kalangan kristiani, di mana institusi Kristen berkolaborasi dengan kekuasaan di berbagai daerah, para pejabat gerejawi di tingkat lokal dengan senang hati menempatkan diri atau ditempatkan sebagai pelayan kekuasaan. ${ }^{6}$ Dengan demikian kekristenan menjadi sekedar alat legitimasi bagi kekuasaan. Tidaklah mengherankan jika pada pilpres 2009, untuk mendapatkan dukungan, maka Jusuf Kala (JK) dan Wiranto berkunjung ke kantor PGI di Jakarta. Keduanya berdialog dengan pimpinan aras nasional Kristen tersebut perihal pencalonan mereka sebagai presiden dan wakil presiden. Tujuannya supaya didukung dan dipilih oleh umat Kristen. ${ }^{7}$

Politisasi agama tidak sesuai dengan semangat kebangkitan Nasional, semangat sumpah pemuda, cita-cita kemerdekaan dan perjuangan reformasi. Indonesia adalah negara Pancasila, bukan negara sekuler, dan bukan teokrasi. Dengan demikian, suatu agama tidak bisa dipaksakan untuk menjadi dasar negara Indonesia. Sebaliknya Indonesia adalah negara yang menghargai toleransi dan menjunjung hak-hak asasi. Dalam kehidupan demokrasi seharusnya agama jangan sampai dijadikan komidat politik. Apabila hal itu dilakukan, maka telah terjadi kelumpuhan hati nurani dan akal sehat di lingkungan para politisi. Menjadikan agama sebagai kendaran politik merupakan sebuah pengkhianatan. ${ }^{8}$ Lalu bagaimanakah sikap etis Kristen terhadap politisasi agama di Indonesia? Itulah pokok bahasan tulisan ini.

\footnotetext{
${ }^{6}$ Einar M. Sitompul (Ed.), Teologi politik: Agama-agama dan Kekuasaan, (Jakarta: Badan Penelitian dan Pengembangan PGI, 2004), h.4

7 "Siapa pemimpin Nasional Pilihan Warga Gereja?" Sorotan Utama dalam Narwastu Pembaruan, No. 68, (Juli 2009), h.24

${ }^{8}$ Eksploitasi Agama, http://www.beritapagi.co.id/read.php, 15 Mei 2010
} 


\section{BAB II \\ DEFINISI, FAKTOR-FAKTOR PENYEBAB, BENTUK-BENTUK, DAN DAMPAK POLITISASI AGAMA DI INDONESIA}

Pembahasan bab dua ini adalah tentang Definisi Istilah Politisasi Agama, Faktor-faktor Penyebab Politisasi Agama, Bentuk-bentuk Politisasi Agama, dan Apa saja Dampak dari Politisasi Agama di Indonesia.

\section{$\underline{\text { Definisi Istilah Politisasi Agama }}$}

Istilah politisasi berasal dari kata dasar politik, yang berarti 1) pengetahuan mengenai ketatanegaraan atau kenegaraan; 2) segala urusan dan tindakan mengenai pemerintahan negara atau terhadap negara lain; 3) cara bertindak kebijaksanaan. ${ }^{9}$ Dalam Kamus Besar Bahasa Indonesia, pengertian politisasi, adalah hal membuat keadaan (perbuatan, gagasan, dsb) bersifat politis. ${ }^{10}$ Politis berarti bersifat politik; bersangkutan dengan politik. ${ }^{11}$ Kata agama berarti sistem, prinsip kepercayaan kepada Tuhan (dewa, dsb) dengan ajaran kebaktian dan kewajibankewajiban yang bertalian dengan kepercayaan itu. ${ }^{12}$

Dengan demikian secara literal arti politisasi agama adalah prinsip kepercayaan kepada Tuhan dan kewajiban-kewajiban yang bertalian dengan kepercayaan menjadi bersifat politis. Politisasi agama mempunyai pengertian sebagai aksi atau praktik politik, ataupun sebuah gerakan politik yang dilakukan dengan mengeksploitasi agama dengan menjadikan agama sebagai kendaraan politik untuk merebut kekuasaan politik. ${ }^{13}$

Pengertian lain dari politisasi agama adalah sebagai berikut:

Politisasi agama adalah politik manipulasi mengenai pemahaman dan pengetahuan keagamaan/kepercayaan dengan menggunakan cara propaganda, indoktrinasi, kampanye, disebarluaskan, sosialisasi dalam wilayah public dilaporkan atau diinterpretasikan agar terjadi migrasi pemahaman, permasalahan dan menjadikannya seolah-olah merupakan pengetahuan keagamaan/ kepercayaan dalam upaya memasukkan kepentingan sesuatu ke dalam agenda politik pemanipulasian masyarakat atau kebijakan publik. ${ }^{14}$

Dari pengertian tersebut dapat dipahami bahwa politisasi agama adalah sesuatu yang sengaja dilakukan dan telah melalui proses yang matang dalam perencanaannya. Politisasi agama memberikan ruang untuk sebuah bentuk

\footnotetext{
${ }^{9}$ Lukman Ali, Kamus Besar Bahasa Indonesia, (Jakarta: Balai Pustaka, 2002), h.886

${ }^{10}$ Lukman Ali, ...h. 887

${ }^{11}$ Ibid.

12 Ibid., h. 10

${ }^{13}$ Leo Yohan Wemay, Sikap Etis Kristen terhadap Politisasi Agama di Indonesia, Skripsi,

${ }^{14}$ Wikipedia, http://id, wikipedia.org/wikipolitisasiagama, 15 Mei 2010
} (Tanjung Enim: STTE, 2010), h.27 
manipulasi terhadap pemahaman dan pengetahuan agama yang dilakukan oleh orang atau sekelompok orang yang ingin berkuasa. Selanjutnya apa yang telah dimanipulasi tersebut disampaikan dalam bentuk-bentuk propaganda dan indoktrinasi yang sungguh-sungguh dengan menggunakan sarana kampanye dalam pemilu, juga melalui sosialisasi dari apa yang dipahami, kepada publik yang diinterpretasikan (ditafsirkan) sesuai dengan maksud pelaku. Selanjutnya supaya maksud yang diinginkan tersebut dapat tercapai, maka dilakukan tekanan-tekanan dengan tujuan untuk sedapat mungkin mempengaruhi konsesus-konsensus keagamaan dengan cara memasukkan kepentingannya kepada agenda politik atau kebijakfr5an publik. ${ }^{15}$ Dari pemahaman ini terkandung makna bahwa di tengah situasi politik yang tidak sehat tersebut, agama telah dieksploitasi untuk kepentingan menundukkan lawan atau menghimpun dukungan baru. ${ }^{16}$ Agama telah diperalat dan dijadikan sebagai kendaraan politik untuk mencapai kekuasaan.

Dengan demikian, politisasi agama berarti tindakan yang dilakukan dengan sengaja terhadap agama untuk dijadikan alat untuk membangun kekuatan dan kekuasaan.

\title{
Faktor-faktor Penyebab Politisasi Agama di Indonesia
}

\begin{abstract}
Adapun penyebab terjadinya politisasi agama di Indonesia antara lain sebagai berikut.
\end{abstract}

\section{Masalah Kekuasaan}

Tidak dapat dipungkiri bahwa setiap manusia cenderung ingin menjadi yang terutama, mengungguli yang lain, ingin dihormati dan dihargai serta menguasai semua sendi kehidupan. Tidak berlebihan jika dikatakan bahwa dalam kehidupan berbangsa dan bernegara juga terjadi hal yang demikian. Berkuasa atau mempunyai kuasa akan membuat seseorang atau sekelompok orang lebih mudah dihargai, dihormati, didengarkan atau bahkan ditakuti. Dalam konteks negara Indonesia yang kekuasaan pemerintahannya melalui proses demokrasi, maka jalan mudah untuk mencapai maksud tersebut adalah melalui politik. ${ }^{17}$

Godaan yang paling besar untuk politisasi agama biasanya ditemui dalam diri para penguasa, dan terutama dalam diri penguasa yang memerintah bersama militer. Sebab ketika kuasa mereka dikritik dan terancam, mereka secara psikologis cenderung untuk menggunakan jalur yang paling kondusif untuk meng-ia-kan kekuasaan mereka. Hal ini ditempuh dalam rangka mempertahankan status quo, melanggengkan kekuasaan dan melindungi bisnisnya. Bidang agama yang memiliki moral universal sebagai pendasar dari satu politik tanpa kekerasan memang dilihat sebagai satu jalur strategis yang bersifat kondusif itu.

Pada tahun itulah (1970-an), Angkatan Bersenjata Republik Indonesia (ABRI) yang pada masa itu merupakan kekuatan nomor satu di tangan Presiden,

\footnotetext{
${ }^{15}$ Leo Yohan Wemay, Sikap Etis Kristen ..., (Tanjung Enim: STTE, 2010), h.28

${ }^{16}$ Hendardi, Demokrasi dan Politisasi Agama, http://cetak.kompas.com/read/xml/ demokrasi dan politisasi agama, 15 Mei 2010

${ }^{17}$ Miriam Budiardjo, Demokrasi di Indonesia, (Jakarta: Gramedia, 1994), h. 198-203
} 
berusaha "merayu" golongan Islam dengan tujuan meraih suara terbesar melalui Golongan Karya (Golkar). Dari kasus tersebut, agama sebagai sentral idelogi sanggup memobilisasi sikap, perilaku individu dan kelompok dalam jumlah besar.

\section{Lemahnya Integritas, identitas, dan Kredibilitas Tokoh-tokoh Agama}

Masalah yang sangat fundamental juga yang menyebabkan terjadinya praktik-praktik politisasi agama di Indonesia adalah karena lemahnya integritas, identitas, dan kredibilitas tokoh-tokoh agama. Tokoh-tokoh agama yang seharusnya menjadi contoh dan panutan umat, justru sebaliknya menjadi pemicu terjadinya politisasi agama. Mereka mau diperalat oleh penguasa dan tokoh-tokoh politik atau bahkan mereka yang memperalat agamanya sendiri untuk memperoleh keuntungan pribadi dan keinginan untuk berkuasa. Hal tersebut membuat mereka merendahkan agamanya, bahkan diri mereka sendiri sebagai pelayan agamanya, demi kepentingan politik. Keadaan yang demikian membuat mereka tidak dapat dipercaya lagi oleh umat, bahkan membuat tercoreng agama sendiri.

\section{$\underline{\text { Bentuk-bentuk Politisasi Agama di Indonesia }}$}

Adapun bentuk-bentuk politisasi agama di Indonesia adalah sebagai berikut.

\section{Agama sebagai alat kampanye partai politik}

Seringkali didapai dalam kegiatan kampanye pra Pemilu, para pemimpin partai politik menggunakan agama untuk alat kampanyenya. Tentang hal ini Stevri I. Lumintang menuliskan:

Pada beberapa tahun terakhir ini, tokoh-tokoh agama tertentu sering menjadi berita di media massa, baik media cetak maupun media elektronik, khususnya pada saat-saat menjelang dan masa kampanye. Mereka didatangi oleh pemimpin-pemimpin partai untuk "membeli" umat atau rakyat. Dalam hal ini, agama menjadi komoditas partai untuk membangun kekuatan demokrasi. Ibadah-ibadah yang dilaksanakan oleh partai, seperti perayaan Natal dan Paskah, sangat rawan diperalat sebagai peluang mencari dukungan massa. Dengan motif "jual-beli" pemimpin gereja mengundang kehadiran ketua partai dalam kegiatan ibadah Natal, sebagai ungkapan dukungan gereja terhadap partai, sekaligus sebagai ungkapan dukungan partai terhadap gereja. ${ }^{18}$

\footnotetext{
${ }^{18}$ Stevri Indra Lumintang, Re-Indonesianisasi..., h. 470
} 


\section{Agama sebagai Alat Legitimasi Kekuasaan Politik Penguasa}

Selain sebagai alat kampanye, agama juga dimanipulasi oleh pemimpin politik dalam masa kekuasaan mereka melalui pemimpin agama. Bukan tidak sedikit, penguasa meminta pemimpin agama untuk menenangkan umat atau rakyat yang mengamuk karena kebijakan penguasa yang merugikan rakyat. Dalam hal ini, pemimpin agama dicari dan diminta menjadi "bodyguard" pemimpin bangsa. Saat Bupati Kutai Barat disidang di Pengadilan Negeri Jakarta dalam kasus korupsi, belasan ulama datang ke Jakarta untuk mengawali jalannya sidang. Bukan tidak sedikit, penguasa yang telah jatuh dalam tindak korupsi, saat di pengadilan menggunakan pakaian dengan simbol agama serta menggunakan istilah-istilah agama sebagai upaya legitimasi perbuatan jahatnya.

Pada Orde Baru, bukan tidak sedikit pemimpin agama "dibeli" oleh pemerintah dengan bantuan bagi agama, berupa pembangunan rumah ibadah dan fasilitas agama lainnya dengan motif untuk menutup mulut mereka terhadap penyimpangan yang dilakukan oleh oknum pemerintah tersebut. Suara kenabian pemimpin agama dibeli oleh kebaikan semu oknum pemerintah. ${ }^{19}$

\section{Agama sebagai Topeng Kekuasaan Ekonomi Penguasa}

Untuk memperoleh kekuasaan politik, pada umumnya politisi akan menggunakan kekuasaan ekonomi. Karena itu, mereka akan mengeluarkan uang dalam jumlah yang besar untuk "membeli" kekuasaan politik. Mulai dari masa kampanye, agama telah dijadikan alat legitimasi kekuasaan ekonomi para calon penguasa. Partai-partai berbasis agama akan cenderung mengatasnamakan agama yang dianut dan dikendarai oleh partai tersebut untuk meminta dukungan dari umat beragama yang kuat secara ekonomi, seperti para pengusaha atau pedagang. Bukan tidak mungkin, para pemimpin partai mengadakan transaksi "jual beli" kekuasaan ekonomi dan politik dengan para pengusaha atau pedagang. Mereka memberikan harta miliknya untuk dana kampanye, dan para pemimpin partai, calon pemimpin bangsa membeli dengan janji-janji berupa proyek-proyek negara, praktik kolusi dan nepotisme sudah dimulai saat kampanye antara penguasa dan pengusaha. Di sinilah pengusaha dan penguasa memberikan keuntungan timbal balik merusak negara. ${ }^{20}$

\section{Agama sebagai Alat Legitimasi Kejahatan Teroris}

Pada umumnya, pelaku tindakan teroris adalah orang beragama dan mengatasnamakan agama tertentu. Citra Islam yang dinodai oleh kelompok teroris terungkap dengan motif balas dendam dan sakit hati. Mereka menyatakan bahwa perjuangan Islam bisa dilakukan dengan semua cara, yaitu moderat, radikal,

\footnotetext{
19 Ibid., h. 474-475

${ }^{20}$ Stevri Indra Lumintang, Re-Indonesianisasi..., h.476
} 
reformis, maupun revolusi. Untuk jihad yang frontal mereka sepakat bahwa cara perjuangan tersebut adalah dengan cara kekerasan dan revolusi.

Sebenarnya agenda utama para teroris Indonesia adalah melawan Amerika Serikat dan sekutu-sekutunya, yang menyerang agama negara-negara Islam. Mereka mengatasnamakan dan menggunakan simbol-simbol Islam dalam memerangi Amerika dan sekutu-sekutunya, sehingga citra Islam menjadi buruk di mata dunia. Kelompok Islam sendiri mengakui tercabiknya citra umat Islam dengan trageditragedi yang dilakukan oleh teroris yang mengatasnamakan perjuangan Islam. ${ }^{21}$

\section{Aksi Massa atas Nama Agama untuk Tujuan Politis}

Sekalipun pada masa Orde Baru, agama sudah biasa dijadikan alat oleh para elite agama dan negara, tetapi mencapai klimaksnya pada masa Reformasi. Agama semakin diperalat dan dijadikan alat aksi massa untuk tindak kerusuhan yang dilatarbelakangi oleh sentimen ekonomi, sosial, etnis, dan agama. Agama ditunggangi oleh kepentingan-kepentingan sosial, ekonomi, dan politik. Sebagai contoh, yang terjadi di Maluku, untuk kepentingan sosial, ekonomi, dan politik, agama dijadikan alat yang diperalat, sehingga mengakibatkan korban jiwa, harta benda, dan fasilitas yang tidak terhitung nilainya. ${ }^{22}$

\section{Agama sebagai Alat untuk Menyerang Negara}

Agama berperan untuk menyuarakan kenabian atau kebenaran dan keadilan kepada pemerintah. Akan tetapi peran ini sangat berpotensi untuk diperalat atau dimanfaatkan oleh pribadi atau kelompok tertentu untuk menyerang bahkan dapat merusak negara.

Semua pemimpin agama dapat menstimulasi atau membakar emosi umatnya untuk mengontrol pemerintah. Tentang hal ini Stevri I. Lumintang menuliskan, Daud Rasyid mengompori para ulama untuk terlibat dalam pelbagai persoalan rakyat. Baginya, seharusnya ulama-lah yang paling bersuara terhadap kasus Aceh, Tanjung Priok, Lampung, dan sebagainya, daripada LSM. Dengan spirit eksklusif, ia pun menegaskan bahwa ulama-lah yang harus lebih vokal menyuarakan pembelaan terhadap hak-hak rakyat karena yang dibantai adalah umat Islam. ${ }^{23}$ Dalam mengomentari hal tersebut, pemimpin agama harus sadar bahwa tugas mengontrol pemerintah bukan dimaksud seperti demikian, tetapi dilakukan untuk kepentingan negara.

\footnotetext{
${ }^{21}$ Ibid., h.477-479

${ }^{22}$ Stevri Indra Lumintang, Re-Indonesianisasi..., h.480-482

${ }^{23}$ Ibid., h. 494
} 


\section{Dampak Politisasi Agama di Indonesia}

Hendardi menyatakan bahwa tidak ada sejarah politik yang mencatat bahwa politisasi agama akan menghasilkan keuntungan politik melimpah. Dia mengambil contoh, politisasi agama dalam UU Pornografi yang telah disahkan pada akhir 2008, terbukti tidak berbuah keuntungan politik signifikan bagi partai-partai pengusungnya. Ini bukti bahwa politisasi agama bukanlah cara berpolitik cerdas dan menguntungkan. ${ }^{24}$

\section{Tidak memberikan Solusi bagi Masalah Bangsa}

Bahaya politisasi agama secara tidak sehat dengan membawa akibat negatif mendorong semua pihak yang bermain politik untuk menempatkan hubungan yang tidak sehat antara kedua bidang itu. Hubungan yang sehat antara keduanya hanya bisa terjamin, ketika keduanya - agama dengan kekuatan moral-spiritualnya dan politik dengan kegiatan strateginya - mengacu pada usaha pemecahan masalah nasional yang bersifat mendasar. Dan dalam hal ini ialah masalah kemiskinan, tekanan ekonomi dan pengangguran yang menimpa bangsa kita tanpa pandang bulu oleh karena krisis ekonomi.

Menjadikan agama sebagai medan pertarungan politis hanyalah mematahkan semangat kita untuk mengkonsolidasikan kekuatan spiritual agama dan membutuhkan jalan strategis untuk membatasi persoalan pokok nasional serta membius kita untuk mengenal problem kita yang sebenarnya. Dengan demikian, agama adalah satu hal pokok yang menjadi masalah prinsipil untuk dibicarakan. Dalam berbagai kasus kekerasan di daerah, misalnya, banyak yang disebabkan berawal pada konflik yang melibatkan agama.

\section{Menciderai Demokrasi}

Politisasi agama dalam praktik politik Indonesia sering terjadi meski tidak pernah memberi kontribusi signifikan pada kemenangan seorang kandidat. Pemilu 2004 misalnya, di mana para kandidat yang diusung berbagai kelompok keagamaan dan memantik emosi umat sebagai salah satu cara mendulang dukungan, nyatanya tidak mengalahkan SBY-JK.

Karakter buruk yang melekat dalam praktik politisasi agama adalah labeling berdasar cara pandang dan sikap diskriminatif terhadap suatu subyek, baik personal maupun golongan, yang pada gilirannya terjadi peminggiran sistematis terhadap subyek dan menghapus hak-haknya untuk diperlakukan setara. Sebenarnya, politisasi agama juga merupakan cara berpolitik yang tidak rasional karena memperdebatkan sesuatu yang bukan merupakan domain politik. Di dalamnya melekat pula pembodohan sistematis kepada publik, suatu yang seharusnya dihindari dalam berdemokrasi. Kontestasi ide menjadi kabur oleh aneka bangunan sentimen identitas. Karena itu, demi penguatan demokrasi yang lebih berkualitas, politisasi identitas

\footnotetext{
${ }^{24}$ Hendardi, Demokrasi dan Politisasi Agama, http://www.freelist. Org/post/ppi/ppiinda, 15 Mei 2010
} 
(agama) wajib dihindari. Berdemokrasi dan berkontestasilah secara rasional dan cerdas dengan memperdebatkan substansi-substansi yang menjawab kebutuhan masyarakat. $^{25}$

\section{Merugikan Banyak Pihak}

Dalam sejarah politik Indonesia, politisasi agama belum pernah meraih keuntungan politik signifikan dalam sebuah kontestasi. Jika ada fase di mana aneka kelompok agama mampu merengkuh dukungan besar, keberhasilan itu tidak pernah konstan dan bertahan lama karena sebenarnya yang mengikat mereka adalah emosi instan dan sesaat, bukan ikatan ideologis permanen. Hasil pemilu legislatif 2009 telah mengonfirmasi sekian kali tesis ini. Sejumlah partai yang selama ini gemar melakukan politisasi tetapi masih tetap mendapat dukungan diyakini disebabkan bukan oleh benefit politisasi agama, tetapi karena kinerja dan agenda-agenda pembangunan yang ditawarkan, yang bisa meyakinkan publik untuk dipilih.

Kesimpulannya, kini politisasi agama tetap menjadi barang tak layak jual dalam kontestasi politik Indonesia. Para politisi di daerah, di tengah otonomi daerah, yang selama ini yakin dengan jalan politisasi agama untuk merengkuh dukungan politik kursi Bupati/ Walikota dengan memproduksi perda-perda agama, saat ini pun meninggalkan cara ini karena ternyata merugikan. Selain itu, dengan menolak ide kesetaraan, penghapusan diskriminasi, dan mengingkari keragaman hakiki bangsa Indonesia, cara ini jelas antidemokrasi. ${ }^{26}$

\section{“Kriminalisasi" Agama}

Dominasi negara yang terlalu besar pada agama, bukan hanya akan membelenggu agama, tetapi juga berpotensi melahirkan tindakan "balas dendam" agama untuk menguasai negara, serta melahirkan gerakan radikal yang kemudian menebar teror di berbagai tempat. Keberpihakan pada kelompok agama mayoritas akan memunculkan isu diskriminasi agama yang akan memicu terjadinya konflik horizontal. $^{27}$

25 Hendardi, Demorasi dan Politisasi Agama, http://cetak.kompas.com/demokrasi dan politisasi agama, 15 Mei 2010

${ }^{26}$ Ibid.

${ }^{27}$ Benyamin F. Intan, Sinar Harapan: “ Efek Berbahaya Kriminalisasi Agama”, 24 April 2007 


\section{BAB III TINJAUAN ETIS KRISTEN}

Etika Kristen berkaitan dengan apa yang secara moral benar dan salah bagi orang Kristen berdasarkan Alkitab. Oleh sebab itu, karena orang-orang Kristen mendasarkan keyakinan di atas wahyu Allah di dalam Kitab Suci, maka Alkitab dikutip sebagai otoritas untuk mengambil kesimpulan. ${ }^{28}$

Bagaimanakah cara menyikapi agama dan politik berdasarkan tinjauan etis Kristen? Politik mempunyai inti pada kekuasaan. Kegiatan politik merupakan proses yang menyangkut perebutan dan mempertahankan kekuasaan dengan kepentingan tertentu. Berpolitik juga berarti bergerak dalam bidang pengaruh antar individu dan kelompok. Lalu, apakah agama bisa menjadi bagian dari proses politik?

Masalahnya, bagaimana bisa menempatkan atau menggunakan agama yang transenden dalam bagian dari proses politik yang bersifat praktis. Memang, dalam beberapa konteks, agama juga menyangkut wilayah praktis, tetapi agama seakan tergeneralisasi menjadi tingkatan praktis.

Penilaian baik-tidaknya atau jahat-tidaknya tindakan berpolitik merupakan satu keharusan di dalam etika, karena penilaian itu termasuk dalam keseluruhan dari praktek penghayatan iman. Dalam terang pemahaman akan nilai ini, satu tindakan berpolitik tanpa moral hanyalah satu permainan kotor, bisnis yang kejam atau satu rekayasa yang menghancurkan sesama.

Membahas tentang politik dan agama, mau tak mau harus menyinggung latar belakang persoalan apakah asas berpolitik itu harus bersifat religius atau sekuler (duniawi). Pokok ini bukan satu hal yang baru dan khas untuk Indonesia, tetapi di mana-mana dalam masyarakat modern tetap merupakan satu persoalan yang harus dijawab dalam etika berpolitik, terutama dalam kehidupan bernegara. Persoalan ini menunjuk kepada dua latar belakang pemikiran yang mempengaruhi sejarah peradaban manusia.

Latar belakang pemikiran pertama yang pada umumnya mewakili sejarah peradaban Barat terletak dalam gagasan bahwa kegiatan berpolitik tidak perlu berdasarkan pada agama, karena kedua bidang itu otonom sifatnya dengan kepentingan yang berbeda. Bentuk pemerintahan yang mencerminkan karakter ini ialah satu pemerintahan sekuler yang memisahkan secara tajam agama dan negara.

Tugas agama-agama adalah melakukan politik agama, bukan politisasi agama. Politik agama adalah politik kenabian (prophetic politics) bukan politik partisan (partisan politics). Politik agama adalah politik moral yang mengeluarkan suara kenabian termasuk melakukan kritik kepada pemerintah dan pejabat publik yang berkuasa, yang tidak menjalankan tugasnya dengan bertanggung jawab. ${ }^{29}$ Agama tidak boleh tidak perduli pada masalah bangsa, tetapi juga tidak boleh diperalat oleh politik. Sedangkan gerakan politisasi agama adalah politik partisan, yang dilakukan dengan mengeksploitasi agama, menjadikan agama sebagai kendaraan politik untuk merebut kekuasaan politik. Sejarah mencatat bahwa apabila agama mengambil alih

28 Norman L. Geisler, Etika Kristen: Pilhan dan Isu, (Malang: Seminari Alkitab Asia Tenggara, 2001), h. 17

${ }_{29}$ Richard Daulay, "Tugas Gereja dalam Dunia Politik," Gema Methodist (Edisi 12 tahun 2009), h. 21 
kekuasaan negara, maka yang terjadi bukan proses demokratisasi dan penghargaan hak-hak asasi, tetapi justru pemerintah yang tirani yang tidak menghargai prinsipprinsip toleransi. Sejarah mencatat bahwa pemerintahan "teokrasi" demikian tidak bertahan lama.

\section{Berdasarkan Teks}

Alkitab memperkenalkan Allah sebagai "Allah yang politis" dan Allah yang hadir dan berkarya dalam sejarah umat manusia di sepanjang masa. Alkitab juga banyak menggunakan terminologi politik untuk menjelaskan hubungan Allah dengan umat-Nya. Orang Ibrani mengenal Allah sebagai Tuan, Raja, dan Penguasa. ${ }^{30}$ Allah memberikan hukum untuk menegakkan keadilan dan perdamaian.

Para Nabi adalah orang-orang yang memberikan perhatian terhadap masalahmasalah yang berhubungan dengan kegiatan politik. Dalam Alkitab dikatakan, bahwa ketika Raja-raja dan penguasa menelantarkan rakyat, tidak membela nasib orang miskin, yatim-piatu dan janda-janda, maka nabi-nabi muncul dan mengkritik pemerintah yang korup itu. Politik kenabian atau gerakan moral agama adalah perjuangan untuk menegakkan keadilan dalam masyarakat (band. Yes. 1:14-17). Gerakan kebangkitan (kebangunan) spiritual selalu bersamaan dengan gerakan menegakkan keadilan sosial (social justice movements).

Dalam Alkitab juga digambarkan bagaimana Tuhan juga dapat memakai politik kekuasaan untuk memuliakan nama Tuhan. Seperti dalam kisah Yusuf yang memegang jabatan kekuasaan, Tuhan memakai politik kekuasaannya untuk menyelamatkan umat-Nya. Demikian juga dengan Daniel dan Ester. Secara tekstual Yesus Kristus memiliki seorang murid yang menjadi anggota kaum Zelot, yang aktif dalam kegiatan politik pada masa itu. Yesus sendiri mengecam orang-orang Farisi dan Saduki yang memperlakukan umat secara sewenang-wenang. Yesus memang tidak terjun langsung dalam politik praktis, tetapi pengajaran dan aktivitas-Nya menunjukkan bahwa Yesus memberikan perhatian terhadap hal-hal yang berhubungan dengan kegiatan sosial, termasuk kepedulian terhadap penindasan kepada masyarakat.

Pemimpin gereja bisa bersentuhan dengan politik melalui politik moral yang mana didasarkan pada Roma 13:1-7, di mana takut akan Tuhan, suatu ketaatan orang Kristen pada Tuhan. Disebutkan pula 6 kriteria yang harus dimiliki pemerintah yang baik yang didasarkan pada Roma 13:1-7 yakni: pemerintah harus memiliki rasa takut terhadap Tuhan, dapat dipercaya, menjunjung tinggi keadilan, mempunyai keberanian, memiliki jiwa berkorban, dan mempunyai jiwa melayani. ${ }^{31}$ Rakyat wajib mendoakan tokoh-tokoh pemerintahan dan menghormatinya (Roma 13:1-2; 1 Pet. 2:13-14).

Orang-orang Kristen boleh menerima dan menjalankan jabatan pemerintahan bila mereka terpanggil untuk itu (Kisah 10:1-2). Namun, harus mampu bersikap benar dalam menghadapi persoalan dan situasi bangsa. (band. Yes. 55:4). Berpartisipasi aktif berarti memiliki kemampuan untuk melakukan tranformasi

${ }^{30}$ Poltak YP Sibarani, Mengukur Demokrasi di Indonesia dan Partisipasi Kristen, (Jakarta: PT Bastela Indah Prinindo, 2007), h. 285

${ }^{31}$ Ibid. 
terhadap negara, sikap keberagamannya dan terhadap berbagai kondisi sosial yang membelenggu dan menderitakan rakyat (Yer. 29:7).

\section{Berdasarkan Konteks}

Sebagian orang percaya menyatakan bahwa gereja hanya berurusan dengan hal kerohanian saja. Agama dianggap sebagai sesuatu hal yang hanya berhubungan dengan kepribadian manusia yang terdalam, bukan "ke luar" kepada masyarakat atau kegiatan sosial-politik. Dengan demikian, dianggap bahwa kekristenan adalah memisahkan Kerajaan Allah dan kerajaan dunia.

Orang percaya yang bersikap demikian berarti menganggap bahwa pengajaran Yesus pada masa lampau tidak dapat diaplikasikan bagi persoalan politik masa kini. Bersikap anti politik dengan alasan bahwa politik selalu menggunakan kekuasaan untuk memaksa, tidaklah mendasar. Justru karena politik dapat disalahgunakan, maka orang percaya harus melaksanakan fungsinya sebagai "garam" dan "terang" dunia. Keterlibatan dalam politik dapat dilakukan dengan berbagai cara. Kegiatan politik tidak hanya melalui partai politik atau institusi politik lainnya yang dibentuk oleh pemerintah, tetapi juga dapat berbentuk kegiatan pada organisasi kemasyarakatan (misalnya LSM). Kegiatan politik demikian sangat baik dilakukan.

Benyamin F. Intan, dalam pemaparannya menyampaikan bahwa umat Kristen harus berusaha mengerti tentang Politik, Moral, dan Kepemimpinan nasional yang berdasarkan Alkitab, meski diakuinya hal itu bukanlah sesuatu yang mudah. Namun setidaknya ada tiga hal yang harus diperhatikan yakni, normatif (principles), situasional (problem), dan eksistensial (person). Dijelaskan pula bahwa politik kekuasaan sesungguhnya tidaklah jahat, namun politik kekuasaan juga tidak netral. Allah merancang politik kekuasaan untuk memuliakan Tuhan, oleh karena itu politik kekuasaan bersifat sakral, kudus, dan bertujuan untuk memuliakan nama Tuhan. Karena itu, kehadiran orang Kristen dalam politik kekuasaan harus menghadirkan Allah, dan bukannya menjadikan politik kekuasaan sebagai Allah, karena politik kekuasaan bukan Allah. ${ }^{32}$

Benyamin Intan juga mengingatkan kepada umat Kristen untuk berhati-hati terhadap jebakan agamanisasi politik dan politisasi agama ketika berkiprah dalam politik, sebagaimana apa yang dialami oleh kekristenan pada masa Konstantinus, dimana pemimpin agama melakukan agamanisasi politik dan disambut oleh Konstantinus yang memanfaatkan agama untuk kepentingan politik (politisasi agama). Secara tegas, ia juga mengingatkan konstitusi agama untuk tidak terlibat dalam politik praktis. ${ }^{33}$

Gereja-gereja harus terus menyuarakan suara kebangsaan. Mengatasi kotakkotak agama, ideologi, etnis dan kota golongan. Gereja akan tetap memposisikan diri sebagai bagian dari bangsa Indonesia, bahwa partisipasi politik gereja-gereja adalah tanggung jawab moral. Kegiatan agama untuk mendirikan dan mengurus partai politik harus dihindari agar tidak membahayakan kesatuan umat.

\footnotetext{
${ }^{32}$ Benyamin F. Intan, Umat Kristen Harus Paham Politik, Moral, dan Kepemimpinan Nasional Berdasarkan Alkitab, http://www.christianpost.co.id.//index.html

${ }^{33}$ Ibid.
} 


\section{SIMPULAN}

Prinsip kepercayaan yang dibuat bersifat politik sesungguhnya adalah tindakan yang dilakukan oleh para elit politik di Indonesia dikarenakan masalah kekuasaan, keinginan untuk mendapatkan posisi penghormatan, penghargaan. Penggunaan agama sebagai alat pencapai kekuasaan juga didukung oleh lemahnya integritas, identitas, dan kredibilitas para tokoh agama yang mau diperalat untuk memperoleh keuntungan pribadi dan keinginan untuk berkuasa.

Politisasi Agama tidak pernah dapat menyelesaikan masalah, justru memperburuk kondisi bangsa, mencederai demokrasi bangsa, dan merugikan bangsa. Sehingga menggunakan agama yang transenden sebagai bagian dalam proses politik praktis tidaklah etis. Tugas orang percaya sebagai warga negara yang bertanggungjawab adalah melakukan politik agama bukan politisasi agama, sebagai garam dan terang gereja harus melakukan politik kenabian.

Orang percaya yang bersikap anti politik berarti menganggap bahwa pengajaran Yesus pada masa lampau tidak dapat diaplikasikan bagi persoalan politik masa kini. Bersikap anti politik dengan alasan bahwa politik selalu menggunakan kekuasaan untuk memaksa, tidaklah mendasar. Orang-orang Kristen boleh menerima dan menjalankan jabatan pemerintahan bila mereka terpanggil untuk itu (Kis. 10:12). Namun harus mampu bersikap benar dalam menghadapi persoalan dan situasi bangsa Orang percaya harus melaksanakan fungsinya sebagai "garam" dan "terang" dunia. Keterlibatan dalam politik dapat dilakukan dengan berbagai cara. Kegiatan politik tidak hanya melalui partai politik atau institusi politik lainnya yang dibentuk oleh pemerintah, tetapi juga dapat berbentuk kegiatan pada organisasi kemasyarakatan.

Kehadiran orang Kristen dalam dunia perpolitikan haruslah digunakan untuk memuliakan Tuhan. Orang Kristen harus berhati-hati agar tidak terjebak dengan agamaisasi politik dan politisasi agama. Takut akan Tuhan adalah dasar politik moral orang percaya dalam bersentuhan dengan politik praktis. Berdasarkan uraian di atas, maka penulis merasa perlu memberi beberapa saran sebagai berikut:

\section{Bagi Hamba Tuhan}

a. Hamba Tuhan adalah pribadi yang memiliki tugas tanggung jawab untuk menggembalakan umat Tuhan. Oleh sebab itu, ia harus sepenuhnya menjalankan tugas tersebut, dan tidak melakukan profesi lain dalam hidupnya. Oleh sebab itu, seorang hamba Tuhan tidak boleh terlibat dalam politik praktis dalam tugas tanggung jawabnya sebagai gembala jemaat.

b. Sebagai kontribusi dalam kehidupan berpolitik, seorang hamba Tuhan harus memperlengkapi diri dengan pengetahuan tentang politik, sehingga dapat memberikan wacana yang alkitabiah tentang politik kepada umat.

d. Memperlengkapai jemaat dengan pengetahuan dan keterampilan politik sesuai dengan iman kristiani.

e. Memberikan masukan dan pendampingan bagi para politisi Kristen yang sedang menjalankan tugas tanggung jawabnya.

e. Tidak menjadikan diri untuk "diperalat" oleh partai politik tertentu dalam mencapai tujuannya. 


\section{Bagi Orang Kristen}

a. Memiliki pemahaman yang benar tentang dunia politik, dan memahami perihal politisasi agama yang terjadi dalam kehidupan bernegara.

b. Tidak bersikap pasif, sehinga dapat memberikan kontribusi dengan memberikan wacana-wacana alkitabiah tentang kehidupan berpolitik dan bernegara.

c. Proaktif memberikan kritik yang membangun apabila terjadi penyimpangan dalam masyarakat, khususnya dalam kehidupan politik kenegaraan.

d. Jika terpanggil untuk terjun dalam politik praktis, harus menjadi politisi yang baik dan benar, sehingga menjadi "garam" dan "terang" dalam kehidupan berbangsa.

e. Sebagai seorang politi, harus bersedia berjuang membela kebenaran demi kepentingan masyarakat.

\section{Bagi Gereja}

a. Gereja harus membantu warganya untuk mengembangkan pendidikan dan keterampilan di segala bidang, termasuk dalam bidang politik.

b. Gereja bukanlah media berpolitik bagi partai tertentu.

c. Gereja tidak boleh mendirikan partai politik.

\section{Bagi Sekolah Tinggi Theologia}

a. Tidak turut serta dalam politik praktis, karena sebagai wadah pembentukan hambahamba Tuhan, sebuah STT adalah lembaga yang bersifat rohani dan netral (tidak berpihak pada partai politik tertentu).

b. Memberikan pengajaran dan keterampilan yang benar tentang politik, baik lewat perkuliahan atau pun kehidupan beroganisasi.

c. Menjadi nara sumber bagi jemaat dalam menyampaikan informasi tentang kehidupan berpolitik dalam perpektif Firman Tuhan. 


\section{DAFTAR PUSTAKA}

Ali, Lukman,

2002 Kamus Besar Bahasa Indonesia. Jakarta: Balai Pustaka

Budiardjo, Miriam,

1994 Demokrasi di Indonesia. Jakarta: Gramedia

Geisler,Norman L,

2001 Etika Kristen: Pilihan dan Isu. Malang: Seminari Alkitab Asia Tenggara

Lumintang, Stevri Indra,

2009 Re-Indonesianisasi Bangsa. Batu: Departemen Multi-Media YPPII

Salim, Peter dan Yeni Salim,

1991 Kamus Bahasa Indonesia Kontemporer. Jakarta: Modern English Press

Sibarani, Poltak YP

2007 Mengukur Demokrasi di Indonesia dan Partisipasi Kristen. Jakarta: PT Bastela Indah Prinindo

Sitompul, Einar M. (Ed.),

2004 Teologi politik: Agama-agama dan Kekuasaan. Jakarta: Badan Penelitian dan Pengembangan PGI

Wemay, Leo Yohan,

2010 Sikap Etis Kristen terhadap Politisasi Agama di Indonesia, Skripsi. Tanjung Enim: STTE

Daulay, Richard

2009 Tugas Gereja dalam Dunia Politik, Gema Methodist. Edisi 12 tahun 2009

Intan, Benyamin F.

2007 Sinar Harapan: "Efek Berbahaya Kriminalisasi Agama", 24 April

2009 "Siapa pemimpin Nasional Pilihan Warga Gereja?" Sorotan Utama dalam Narwastu Pembaruan, No. 68, Juli 2009

Hendardi,

2010 Demokrasi dan Politisasi Agama, http://www.freelist. Org/post/ ppi/ppiinda, 15 Mei 
Hendardi,

2010 Demorasi dan Politisasi Agama, http://cetak.kompas.com/ demokrasi dan politisasi agama, $15 \mathrm{Mei}$

Intan, Benyamin F.,

2010 Umat Kristen Harus Paham Politik, Moral, dan Kepemimpinan Nasional Berdasarkan Alkitab, http://www.christianpost.co.id.//index.html

2010 Agama dan Politik, http:/www.Ambil-free.com, $15 \mathrm{Mei}$

2010 Eksploitasi Agama, http://www.beritapagi.co.id/read. php, 15 Mei

2010 Wikipedia, http://id, wikipedia.org/wikipolitisasiagama, 15 Mei 